\title{
اليورانيوم المنضب \\ واستخدامه امريكياً في العراق
}

$$
\text { دركز الدراسات الدولية حمد السعدون }
$$


اسباب كثيرة استوجبت ان نتتاول بحث هذا الموضوع لأهميته القصوى في حياة العراقيين ، حاضراً

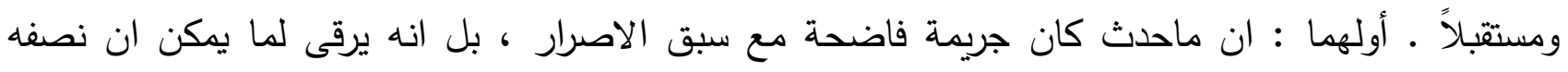

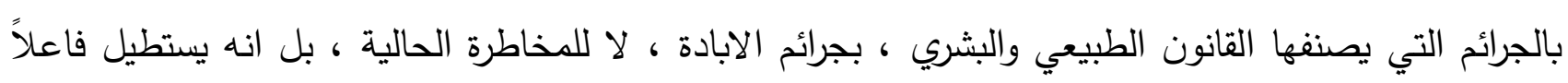

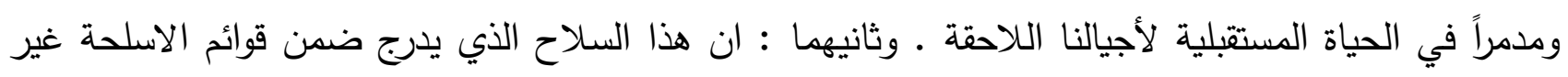

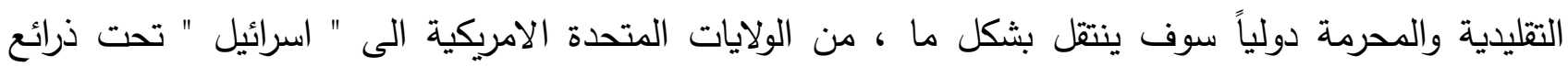

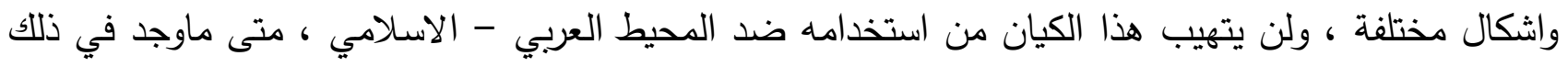

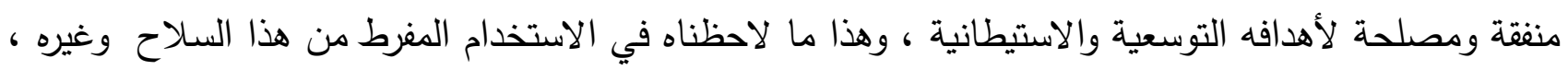
في الحرب التي شنتها " اسرائيل "ضد قطاع غزة عام 2008 ـ دون ان نسقط من اعتبارنا ، مهما كانت اشكال

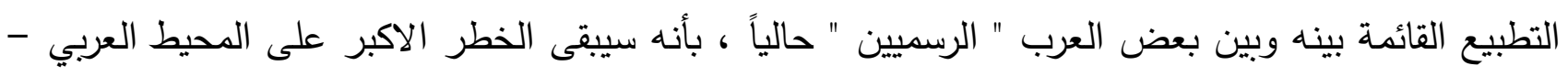

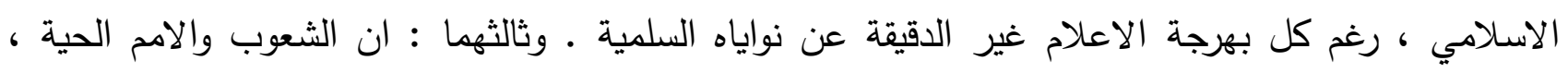

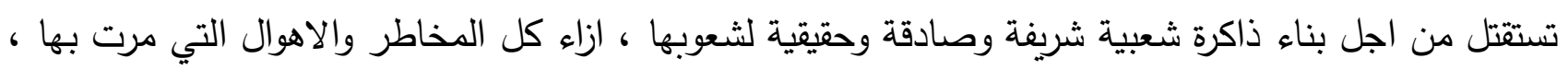

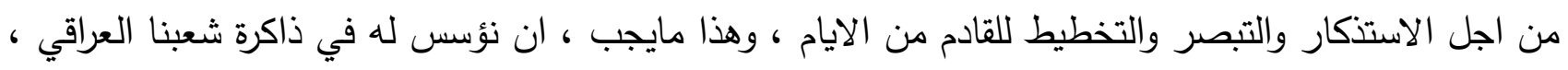

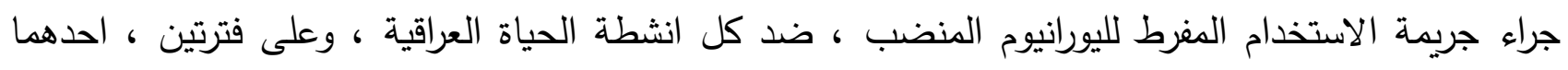

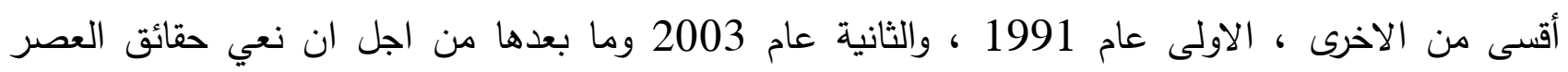
وموازينه وطغاته ، حفاظاً على الوطن الذي يتقدم على كل الاشياء ، رغم كل الضجيج المفتعل والمفبرك دفاعاً

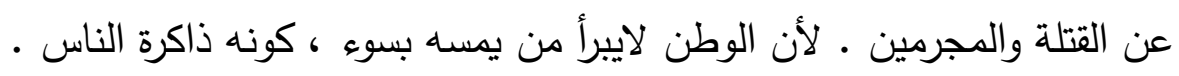

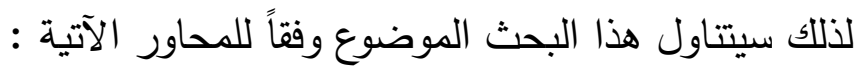
أولاً : افتضاح جريمة استخدام اليورانيوم المنضب ، وما سببه هذا الاستخدام من مآسي ، وسعي منفذيه لطمس

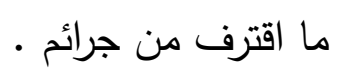

ثانياً : التعرف على اليورانيوم المنضب علمياً ، وتحديد وجوده وانواعه واثاره الصحية والبيئية .

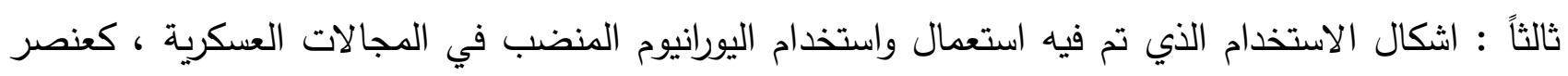
حاسم في حصول المواجهات العسكرية . رابعاً : الوقوف عند ازمة اليقين والمصداقية التي واجهها العالم جراء استخدام اليورانيوم المنضب ، في مجالات

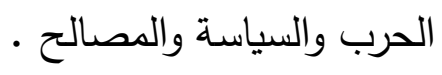


حينما سقط مئات من جنود حرب الخليج والبلقان بعد عودتهم الى ديارهم ، ضحايا لأمراض

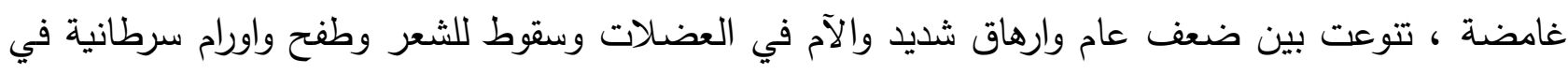
الجلد والدم ، اودت بعدد منهم الى الموت ، بات الأمر اشبه ان يكون وكأنه لعنة نزلت من السماء لتعاء لتعاقب من

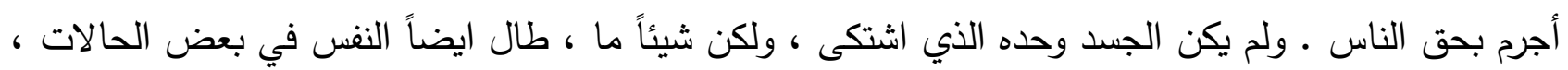

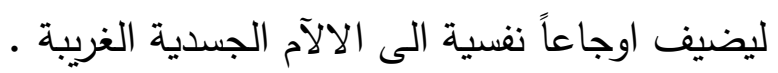

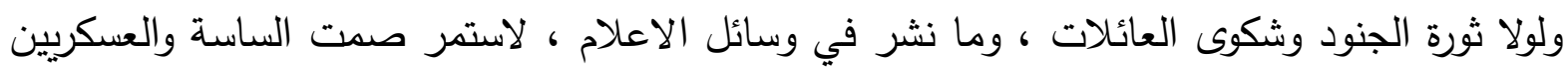

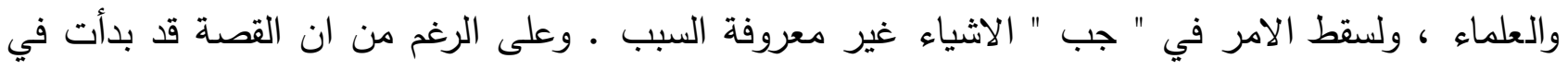

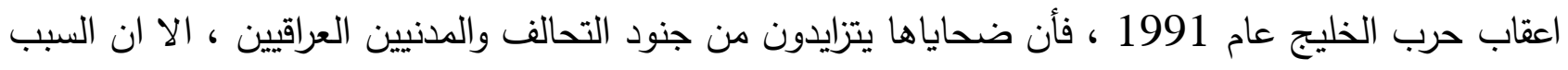

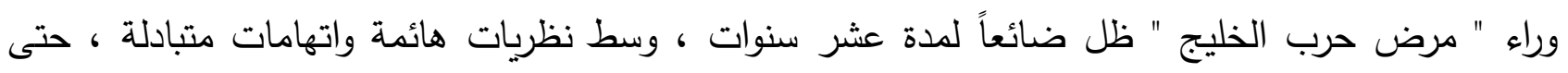
ضرب " مرض حرب البلقان " جنود حلف الناتو من الاوربيين بعد العدوان على يوغسلافيا عام 1999 ، فبات

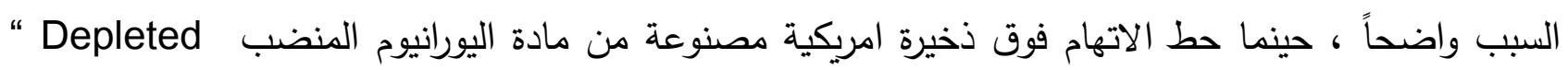

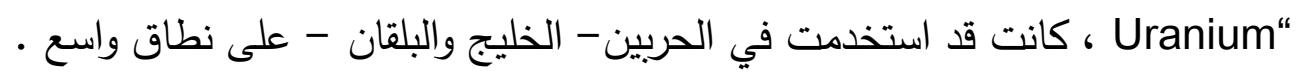
ولم تكن هي المرة الاولى التي تردد فيها الحديث حول تللك الذخيرة ، وخاصة من الجانب العراقي ، الا

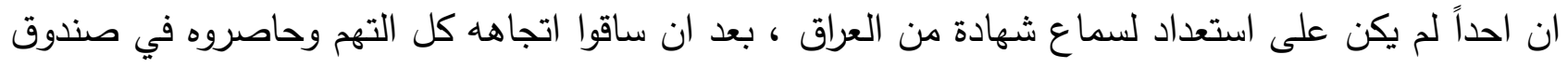

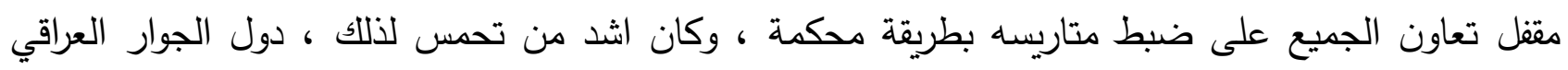

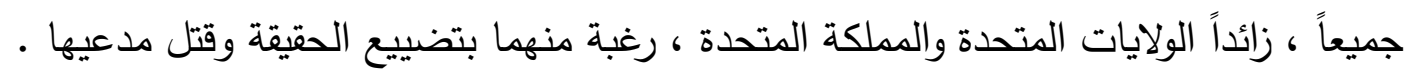

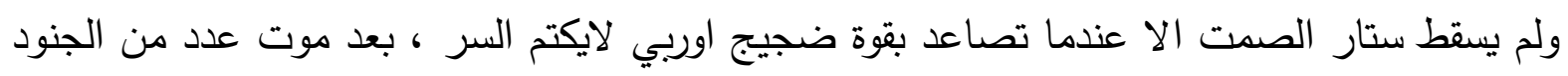

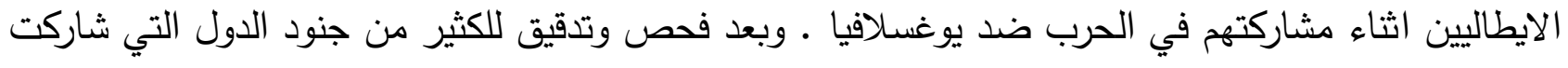

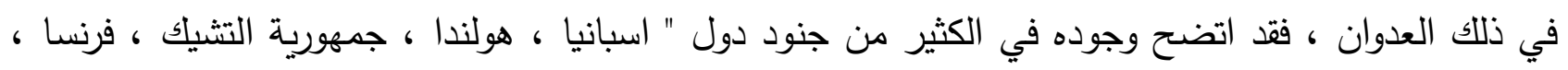

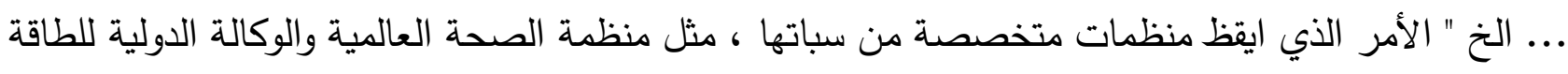

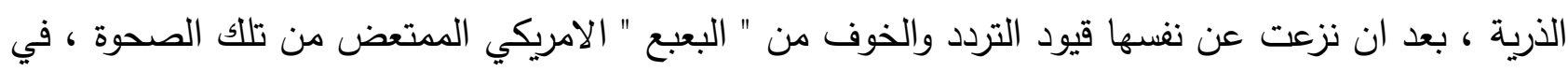

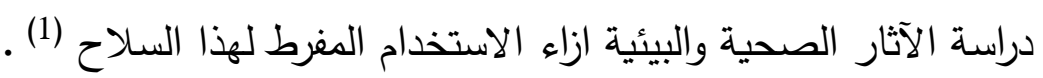

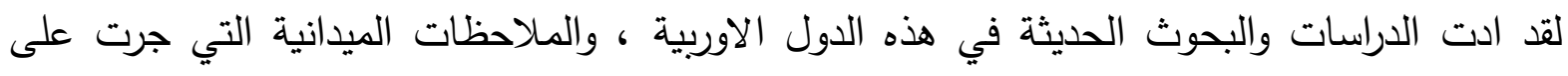

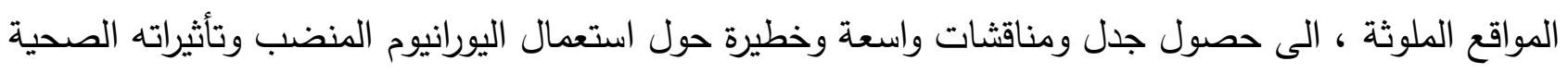

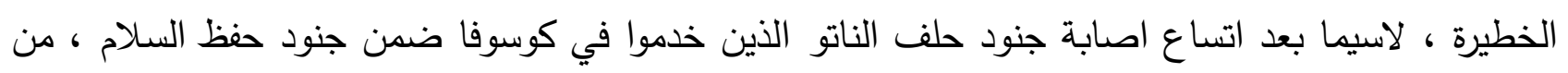

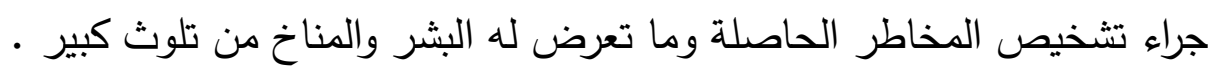

1 - . جاك بيولي ، البوسنة و الهرسك : ابادة بدون رادع ، ترجمة د. صالح المخزوم ، منشورات المؤسسة العربية للنشر والابداع ، الدار البيضاء (بدون تاريخ) ص : 38 - 54 . 
لقد واجهت الولايات المتحدة هذه الحملة بالازدراء وبالادعاءات الهستيرية، كونها - مثلما تدعي - تثتقر للبرهان العلمي المباشر (1) ، على الرغم من ان دلائل ماحصل وقائع لاتخطئها العين المجردة ، وهذا مابينته

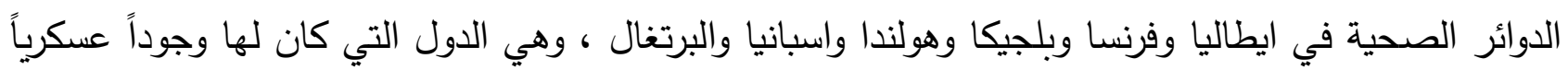

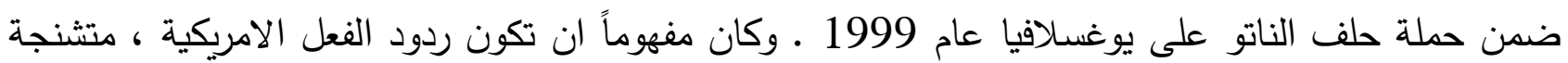

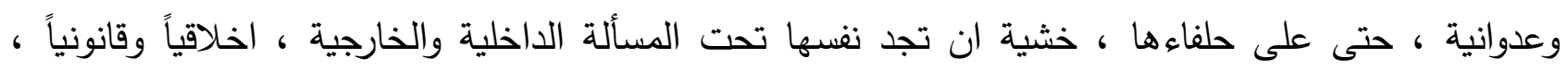
لاسيما وان اتفاقيات جنيف الدولية الخاصة بالاستخدام السلمي للطاقة النووية ، والموقع عليها من قبل الولايات المتحدة ، تدين مثل تلك الافعال والسلوكيات ـ والازمة التي تفجرت بسبب هذه الذخيرة ، بعد عقد كامل من بدء لاء

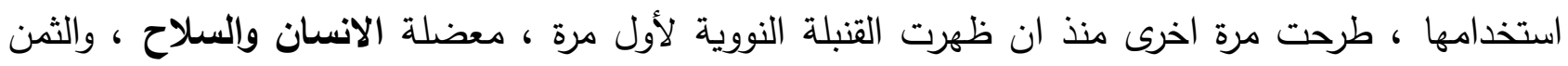

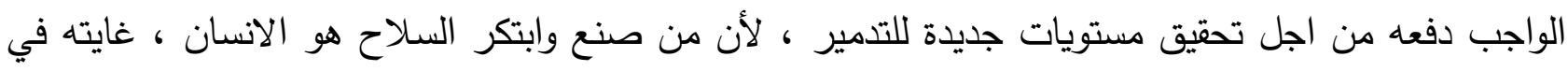

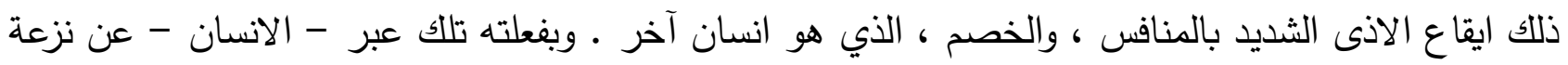

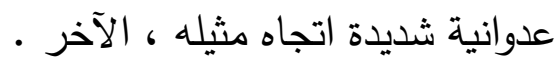

كما طرحت استخدامات هذه الذخيرة معضلة العلم والعلماء ، عندما يخوضون في مسائل مركبة متعددة

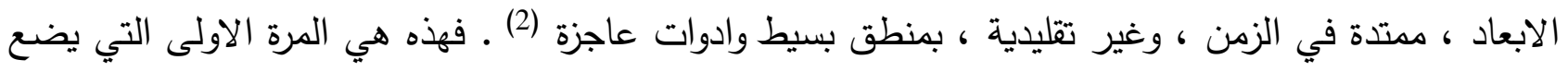
العلماء في يد " الجندي العادي " ذخيرة مشعة ، ويقبلون بمخاطر استخدامها وتداولها الصحية والبيئية ، معبرين في ذلك عن الاستخدام العبثي للعلم ، حينما يوجه لغايات واهداف تتقاطع وانسانية العلم ، الذي ماوجد الا لخدمة الانسان من خلال تطويع المصاعب وتسهيلها بوجه تطلعه الحياتي . كما طرحت هذه الازمة ، قضية التجريب في الحرب وتحول ميدان القتال الى معمل لحروب المستقبل

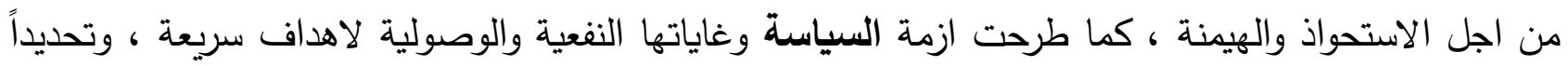

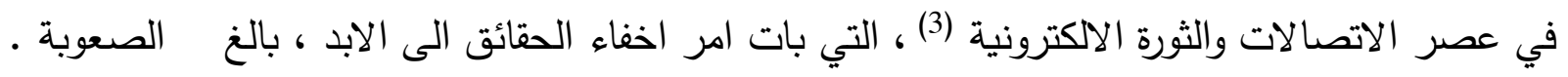

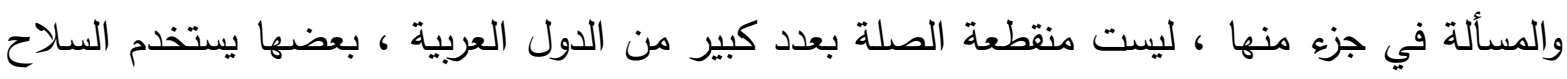

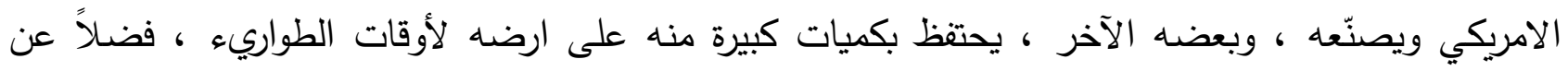

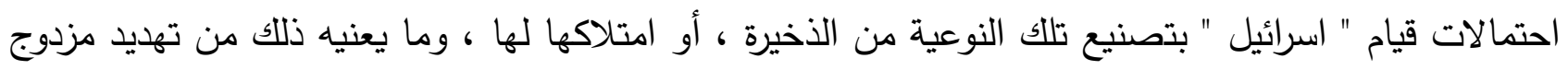
• عسكري وبيئي

ثانيا: اليورانيوم المنضب

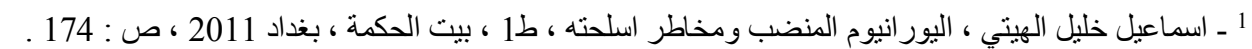

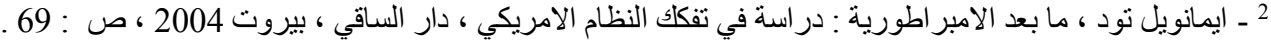

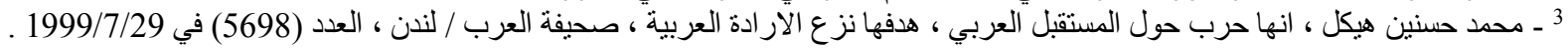


يعرف اليورانيوم المنضب ، بأنه الناتج المتخلف عن عملية تخصيب اليورانيوم ، وهو ذو نشاط إشعاعي ، إضافة إلى كونه من العناصر الثقيلة ذات الذرات القلقة والمشعة ـ وتعد ذرة اليورانيوم ، اثقل ذرة ، ولها وفرة " البلوتونيوم

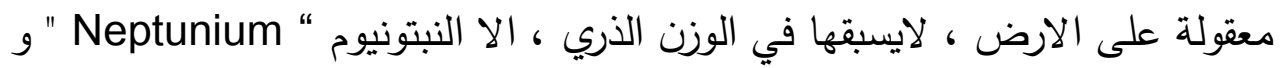

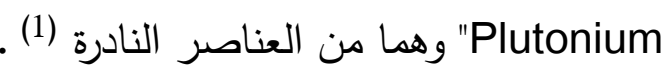

ومن بين الاسباب التي اغرت العلماء باستخدام اليورانيوم في تصنيع الذخيرة ، انه لايعتبر عنصراً نادراً ،

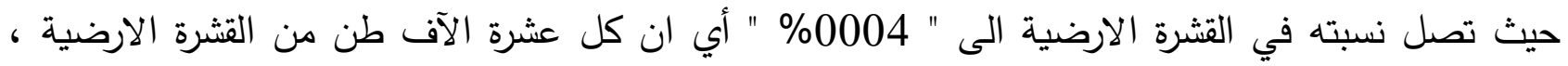
يحتوي على اربعة اطنان من اليورانيوم ، وهي نسبة عالية مقارنة بالكثير من العناصر الاخرى ـ فهو على سبيل

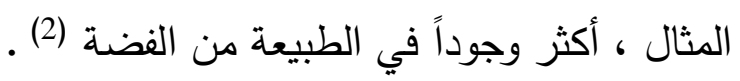

ومعدن اليورانيوم في صورته الخالصة ، فضي اللون ، وينصهر عند " 1132 " درجة مئوية ، وتشتعل

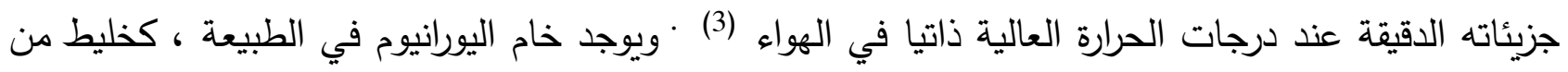
ثلاث نظائر مشعة .

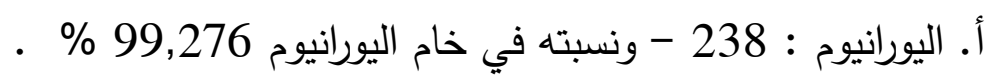

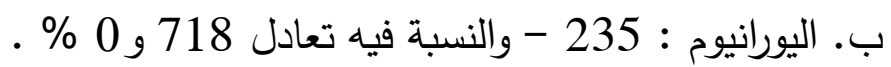

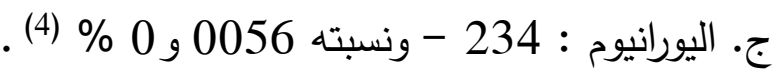
ويعد اليورانيوم المنضب ، فلزاً ثقيلاً ساماً ، يمكن ان يسبب تسمماً كيميائياً بالطريقة نفسها التي يسببها الرصاص ، وأي فلز ثقيل آخر • وهو مادة محرقة وسامة ومشعة ، وتكون خطورته اكثر في حالة اشتعاله. فضلاً عن ذلك ، فأنه قابل للطرق والسحب والصقل ، ولين وذو كثافة عالية ، حيث يساوي " 1,7 مرة بقدر

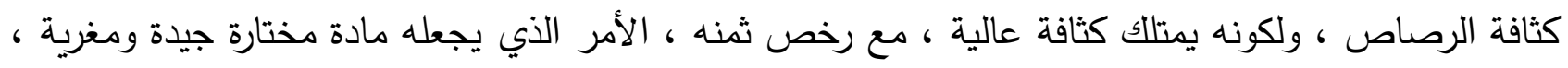
لصنع هياكل الطائرات المضادة للوزن ، وفي صناعة الدروع الحربية الواقية ، اضافة الى الدروع المضادة للذخيرة (5) . لمنح اما استخدامات اليورانيوم كوقود للمفاعلات النووية فأنه يتم من خلال تخصيبه ، بزيادة تركيز النظائر

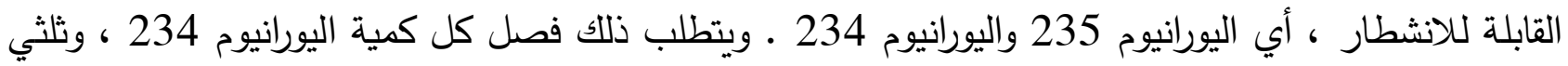

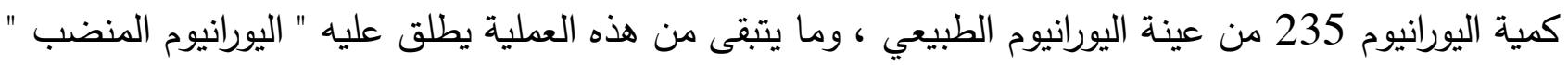

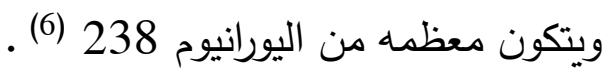

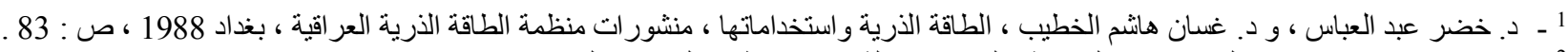

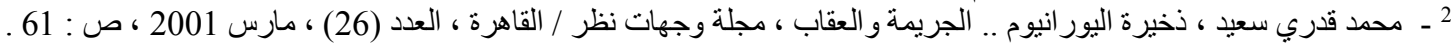
3 - J.S. Przemienieck “ ed “, Critical Technologies for National Defense, US Air Force Institute of Technology, ( AIAA ), Washington 1991, P : 74 .

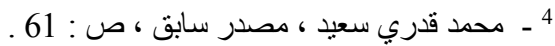

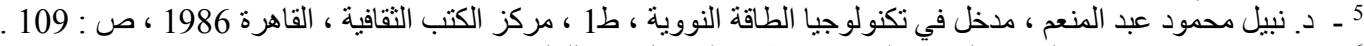
6 ـ ـ عماد خذوري ، سراب السلاح النووي العر اقي ، ط1 ، الدار العربية للعلوم ، بيروت النية 2005 ، ص : 118 ـ 
والاشعاع الصادر من اليورانيوم المنضب ، يقل بنسبة " 40 \% " من مستوى الاشعاع الصادر من خام اليورانيوم في صورته الطبيعية ـ اما باقي الخصائص الطبيعية والكمياوية ، ودرجة السمّية ، فهي منطابقة في

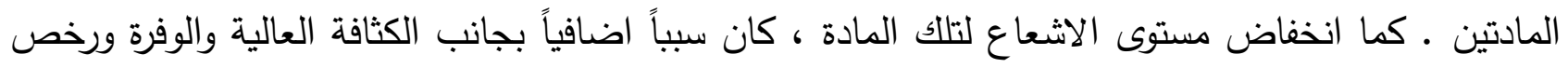
الثمن ، لاختيارها لتصنيع الذخيرة (1) .

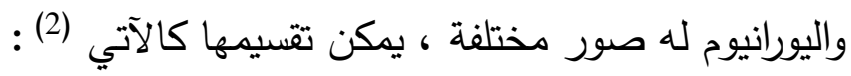

\begin{tabular}{|c|c|}
\hline النسبة & أ . اليورانيوم الطبيعي \\
\hline$\% 0,0056$ & • يورانيوم 234 \\
\hline$\% 0,718$ & • يورانيوم 235 \\
\hline \multirow{2}{*}{$\% 99,276$} & ع يورانيوم 238 \\
\hline & ب ـ اليورانيوم المنضب \\
\hline$\% 0,02$ & • يورانيوم 234 \\
\hline$\% 0,02$ & • يورانيوم 235 \\
\hline \multirow[t]{2}{*}{$\% 99,8$} & يورانيوم 238 \\
\hline & ج. اليورانيوم المخصب \\
\hline اثار قليلة & * يورانيوم 234 \\
\hline$\% 90-3$ & * يورانيوم 235 \\
\hline$\% 97-10$ & * يورانيوم 238 \\
\hline
\end{tabular}

وفيما يخص اليورانيوم المنضب ، فأن استخداماته تتم في تصنيع الذخيرة المضادة للدروع التي تطلق من مدافع الدبابات والطائرات ، وفي تصنيع الرؤوس الحربية للصواريخ المضادة للدبابات ، ويدخل لضبط الطائرات

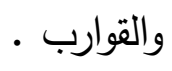

اما اثاره الصحية والبيئية ، فله تأثيرات كيمياوية واشعاعية سلبية على صحة الانسان ، فضلاً عن ذلك،

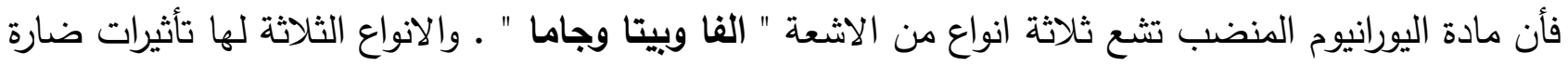

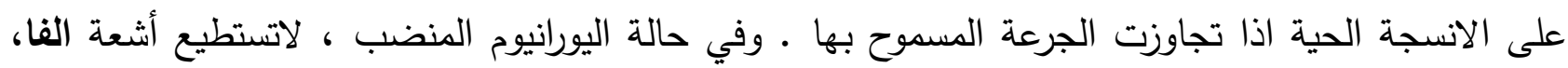

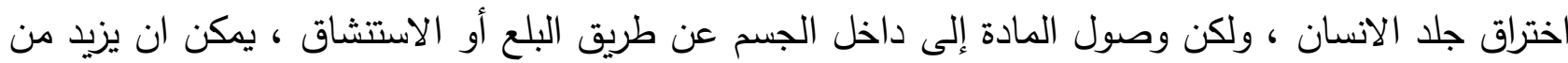

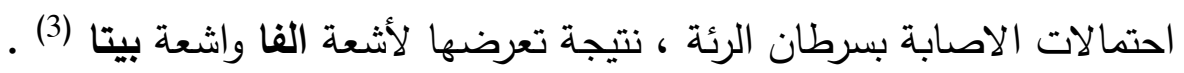
وقد ارجعت الكثير من الدراسات التي تعقبت آثار هذا المرض ، ان سبب حدوث سرطان الدم ، عائد

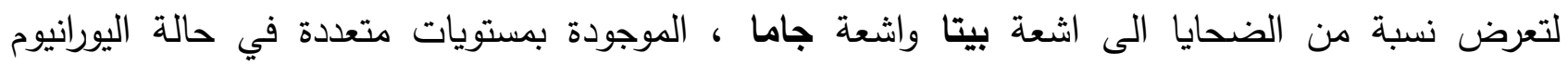

1 - ـ محمد قدري سعيد ، مصدر سابق ، ص : 61 .

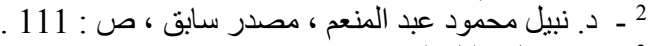

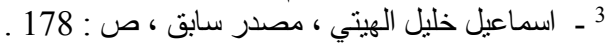


المنضب، كون ان الاشعاع الذي يخلفه يسبب مزيداً من الاذى الاشعاعي للاحياء ـ فضلاً عن ذلك ، انه عند

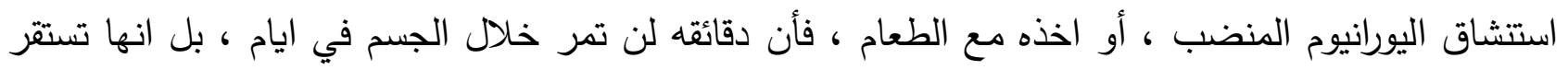
في الرئتين لسنين ، وفي العظام حتى الموت ، مع استمرارها في بعث الاشعاع الثعان الدائم (1) .

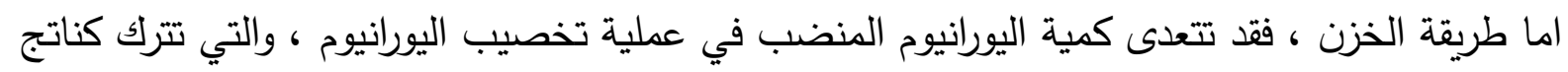

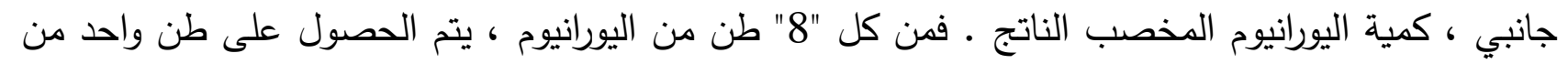

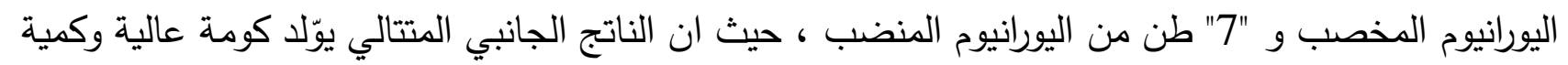

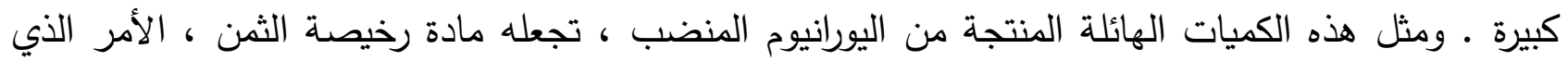
يستوجب خزنها بصورة امينة ومشددة ، بعيداً عن الاستخدام العبثي كون ان فعاليته ذات طبيعة استمرارية (2) .

ثالثاً : الاستخدام العسكري لقد كان التلازم الحاصل بين الاختراعات العلمية وطريقة توظيفها في الاستخدام العسكري ، أحد أهم

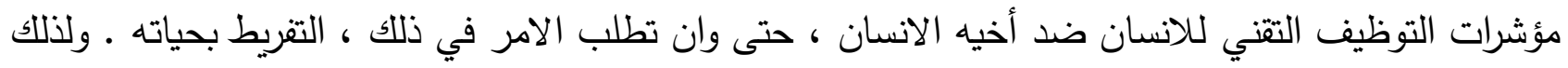
جرى الاستخدام - حد الاسراف - في هذا الجانب ، بأشكال متعددة ، وصلت قتها يوم جرى ضرن ضرب مدينتي "

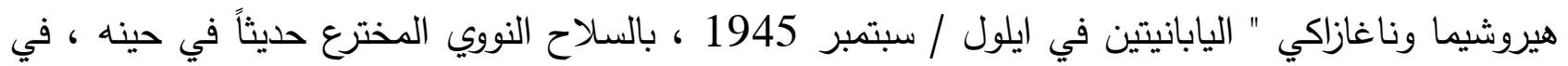

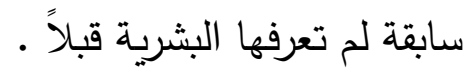
ورغم الادانة الدولية لتلك التجربة ، الا ان القوى النافذة على المسرح السياسي ، لم تفكر او تحاول

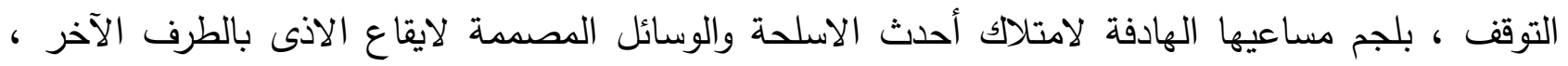

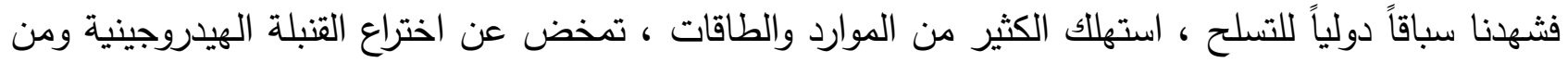

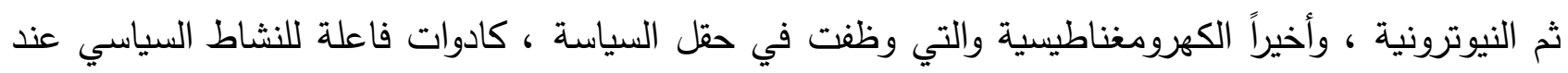

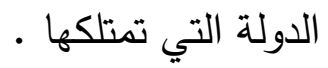

وفيما يخص مادة اليورانيوم المنضب ، فقد كان ميل المخترعين لاستخدامه ، ينصب اساساً لمعالجة المركبات العسكرية المدرعة ، وتحديداً الدبابات والمدرعات ، بحكم متانتها وقدرتها على التأثير في ميدان المعركة ـ ولذلك انصب جهد التطوير لاخراج هذه المركبة من ميدان المعركة وقتل طاقمها ـ دون ان نغفل ان الطرق التقليدية الثائعة لقتل الافراد وتدمير المعدات في الحرب ، تتحور في طريقتين : الاولى : كيمياوية ، تستخدم المواد شديدة الانفجار لتوليد طاقة ضغط وحرارة كافية لأعطاب الهدف وتدميره والقضاء عليه ـ وقد استخدمت القوات الامريكية الغازية عام 2003 ، هذه الطريقة في معارك مطار بغداد وفي القصف الصاروخي والجوي على مراكز القيادة والسيطرة العراقية ، وعلى معسكرات الجيش وتجمعاته (3) .

1 ــ د. صلاح الدين كمال ود. محمد جمعة ، الاشعاع الذري ، ط1 ، دار الر اتب الجامعية ، بيروت 1984 ، ص : 117 ، 109

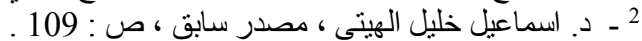
3 ـ الفريق الركن رعد مجيد الحمداني ، قبل ان يغادرنا التاريخ ، ط1 ، الدار العربية للعلوم ـ ناشرون ، بيروت 2007 ، ص : 323 ـ 
كذلك اعيد استخدام هذه الطريقة في معارك الفلوجة عام 2004 ، الامر الذي اذهل فريقاً طبياً بريطانياً

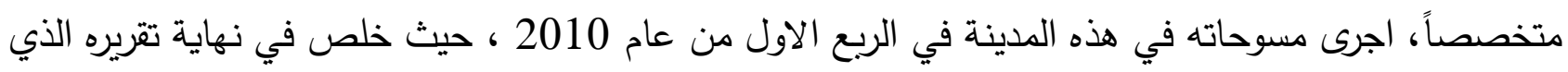

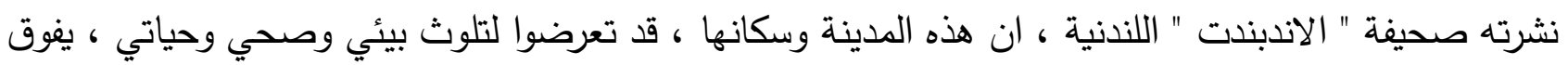

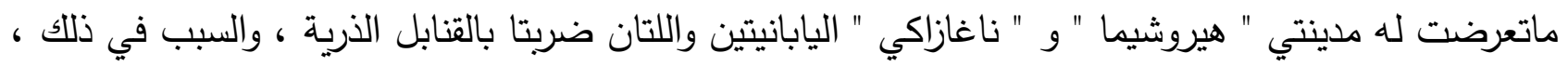
الاستخدام المفرط للاسلحة المحرمة التي استخدمتها القوات الامريكية ضد سكان هذه المدينة ، وتحديداً الاسلحة

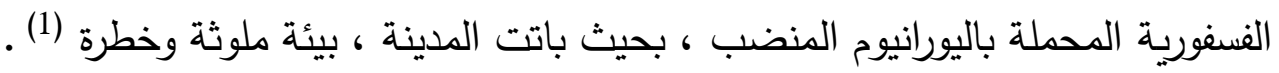

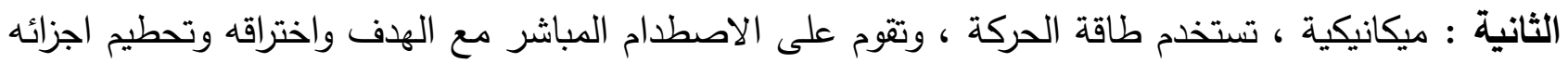
الحيوية من الداخل ـ وقد مارستها القوات الامريكية والبريطانية ضد القوات العراقية في معركة عاصفة الصحراء

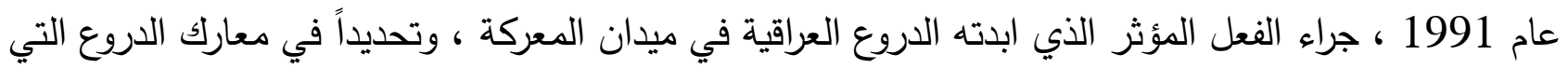
جرت جنوب البصرة ، اواخر شباط / فبراير 1991 (2) ـ وقد كانت تلك المرة الاولى التي يجري فيها استخدام فعلي لذخيرة اليورانيوم المنضب في المعارك العسكرية ، وسمّيت المقذوفة التي استخدمت من قبل الجنود

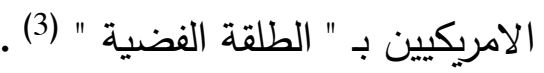

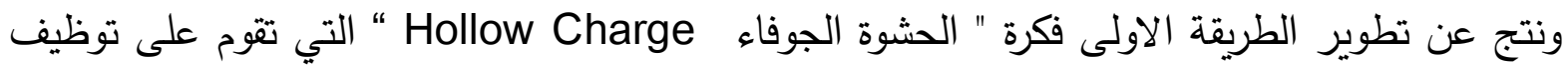
الخصائص الكيمياوية والفيزياوية لليورانيوم من خلال تفريخ رأس المقذوف من المواد شديدة الانفجار ، الأ من كمية صغيرة يوضع امامها مخروط من النحاس ، وقبل ان يلمس المقذوف درع الدبابة ، تتفجر شحنة المتفجرات الصغيرة ، وتحول مخروط النحاس ، الى تيار سريع ساخن من النحاس المنصهر ، يذيب الدرع ويخرقه في ،

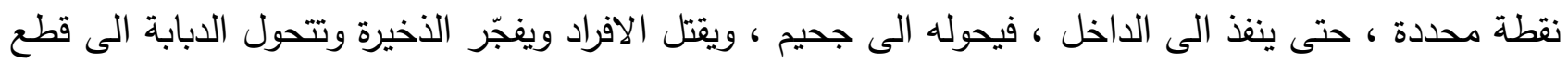

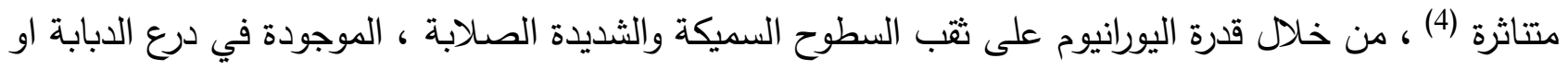

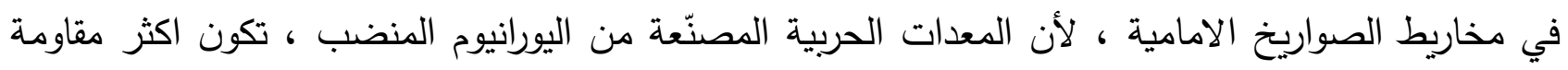
وقدرة لنفاذ ذخيرتها الحربية في الصفائح الفولاذية القوية التدريع(5). وقد طبق الامريكيين ذلك الاسلوب في معاركهم ضد قوات الحرس الجمهوري عام 1991 ، في المنطقة المحيطة بالبصرة • وعلى الرغم من ارجحيتهم القتالية ، لكنهم لم يستطيعوا ان يخترقوا السد الناري العراقي • اما فيما يخص الطريقة الثانية - التدمير بطاقة الحركة - فجرى تطويرها عن طريق زيادة سرعة

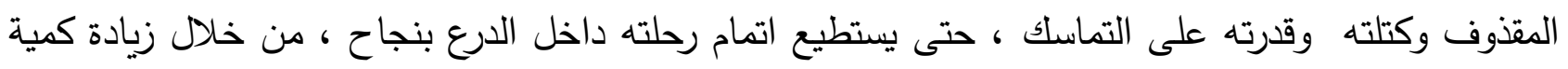

$$
\begin{aligned}
& 1 \text { - - صحيفة المشرق / بغداد ، العدد (1856) في 2010/7/25 . }
\end{aligned}
$$

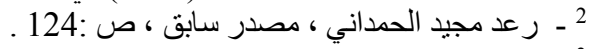

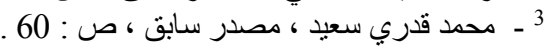

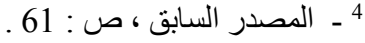

$$
\begin{aligned}
& 5 \text { ـ ـ عماد خدوري ، مصدر سابق ، ص : } 50 \text { ـ }
\end{aligned}
$$


اليورانيوم المنضب كمادة قادرة على اتمام المهمة المطلوبة ، بتوظيف قدرته القوية على النفاذ ، من خلال الثقب الذي يعمله عند اصطدامه بالسلاح الحربي للعدو (1) . وقد مارس الامريكيين هذا الاسلوب في عدوانهم على العراق عامي 1991 و 2003 ، في عموم مواجهاتهم مع القوات العراقية ـ بل انهم وازاء صلابة المقاومة العراقية الثديدة لعدوانهم ، فأنهم لم يترددوا في استخدام اسلحة نووية تكتيكية للحصول على الارجحية في ميدان القتال ، وهذا ماحصل تحديداًفي معارك مطار بغداد (2) ب (2)

شكلت المخاطر البيئية والصحية المحتملة ، هاجساً مستمراً بالخطورة منذ ان بدأ التفكير في تصنيع ذخيرة مضادة للدروع من مادة اليورانيوم المنضب ـ والهاجس الاكبر في موضوع ذخيرة اليورانيوم ، كان الغبار الششع الناتج عن اصطدام الذخيرة بالدبابة أو بالمدرعة او تعرض الذخيرة للحريق وماينتج عن ذللك من اكسيد

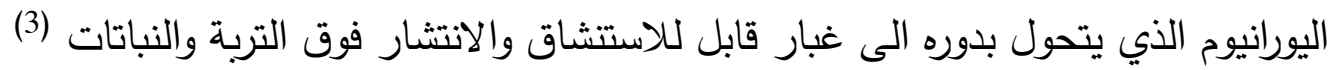
وقد رصدت الجهات الصحية العراقية المخاطر الحاصلة من الاستخدام المفرط لمادة اليورانيوم المنضب لإنب في حرب 1991 ، واصدرت دراسة بينت فيها الاثار الخطيرة على الجنس البشري والبيئة ، بسبب ان المقذوفة الحاملة لليورانيوم المنضب ، تتحول بعد اصطدامها بالدبابة أو بالمدرعة ، الى ثاني اكسيد ، يفرز امواجاً

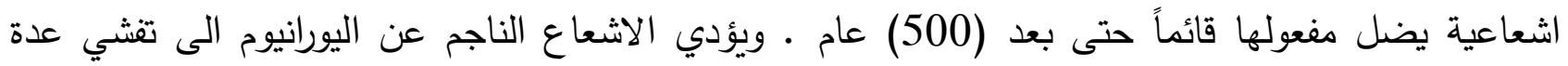
امراض ، ولاسيما السرطان وضغط الدم والتشوهات الخلقية ، وغيرها من الامراض ، وهذا مالاحظناه في

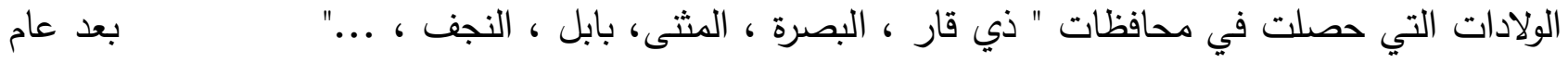

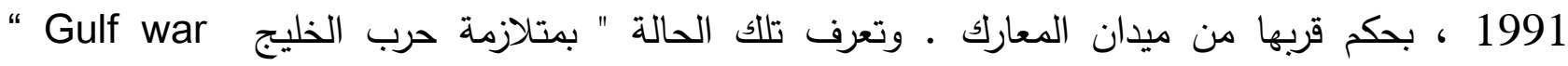
. (4) syndrome لقد استخدت كافة تشكيلات القوات العكرية الامريكية ، ذخيرة اليورانيوم المنضب اثناء حرب عام 1991 ـ والملاحظات التالية تعرض باختصار حجم استخدام تلك المادة في تلك الحرب (5 ) : 1. استخدم الجيش الامريكي في حرب 1991 ، (594) دبابة ثقيلة نوع (M1A1 ) يدخل في بناء درعها

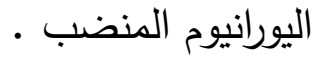
2. اطلقت المدرعات الامريكية (9552) طلقة يورانيوم اثناء الحرب ، تزن في مجموعها (50) طناً .

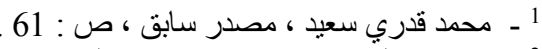

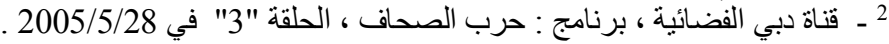

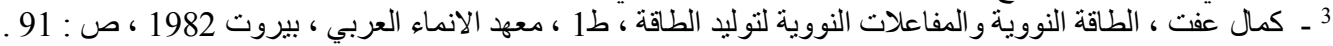

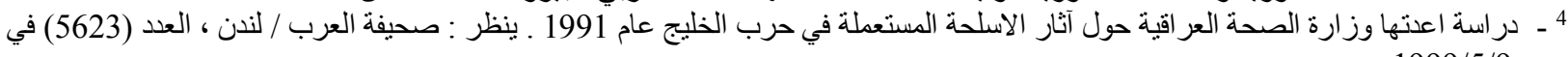
1999/5/9

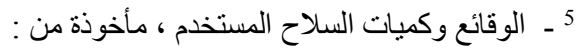
Environmental Exposure Report : Depleted Uranium in the Gulf “ II “, office of special Assistance for Defense, Report No : “1- 800 - 497 - 6267 “ December 13.2000 . 
3. استخدمت القوات الجوية طائرات (A.10) على نطاق واسع ضد حشود الدبابات العراقية ، واشترك منها في الحرب (148) طائرة ، نفذت (8077) طلعة ، اطلقت فيها (A83514) طلقة عيار (30 ملم ) تزن حوالي

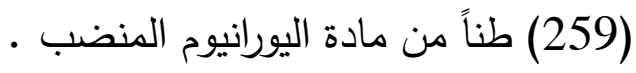

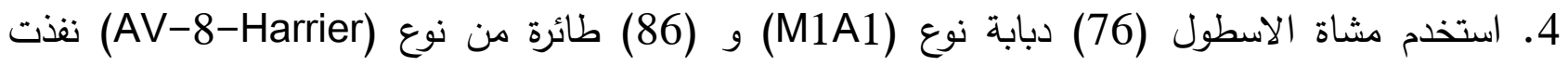

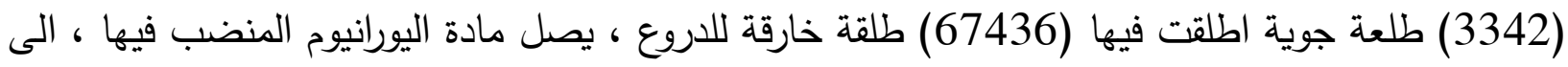
حدود (11) طن •

ولابد من الاشارة لافتقارنا الى اي عدد رقمي معتمد ، عما استخدمته الولايات المتحدة الامريكية ، من

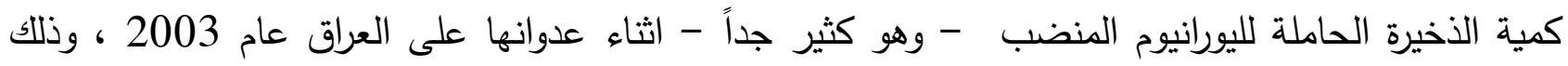

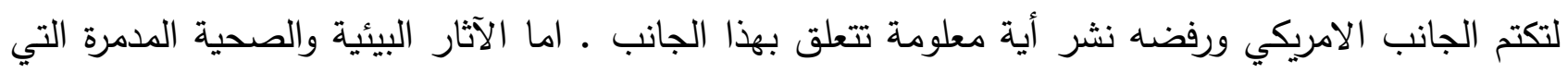

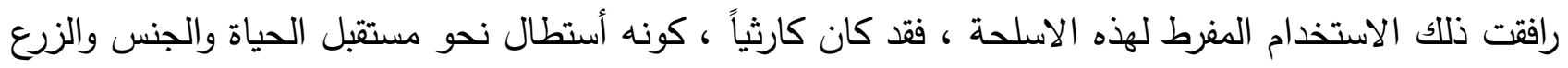

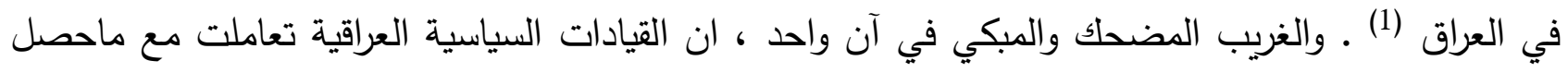

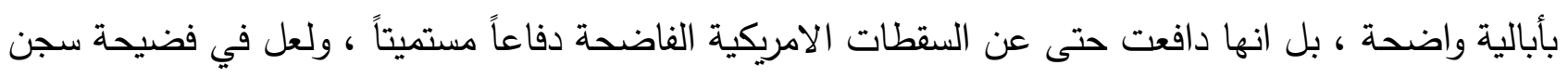
ابو غريب المثل الصارخ لذلك الاهمال واللاابالية ، على الرغم ان ماحدث شكل فضيحةً وانحداراً اخلاقياً

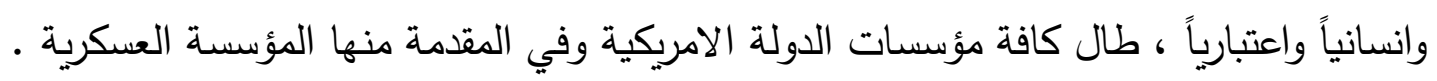

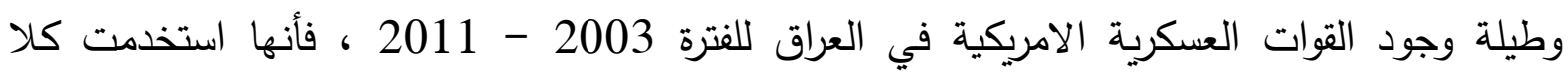
الطريقتين ضد المدنيين العراقيين ، لاسيما ضد المقاومين لوجودها ، وتحديداً في مناطق وسط وغرب العرب العراق ،

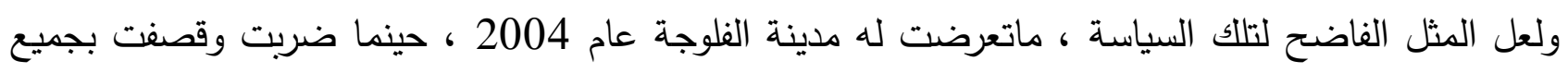

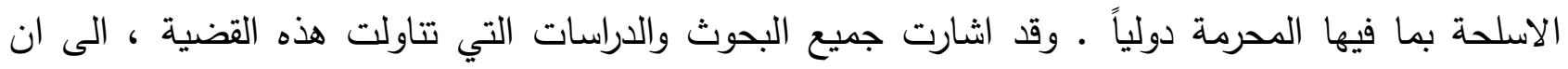

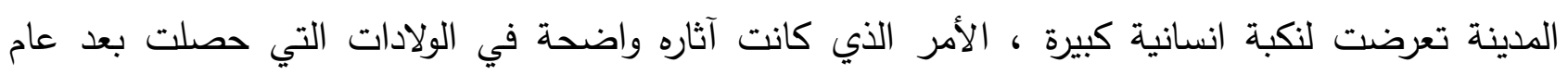

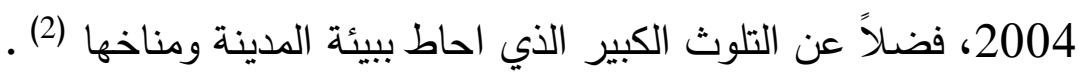

رابعاً : أزمة يقين ومصداقية تثير مشكلة امراض الحروب التي تعرض لها العراق بين 1990 - 2003 ، وعلاقتها بذخيرة اليورانيوم

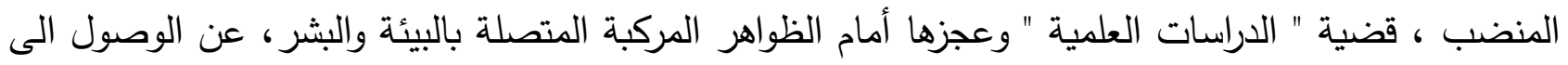
نتائج واضحة ومفهومة ومؤكدة • ولاشك ان العجز يتزايد ، وربما يتحول الى انحراف متعدد ، اذا اضفنا الى لى ذلك الحرب والسياسة والمصالح ، حينما يجري تركيب القناعات السياسية على ادلة كاذبة لغرض الترويج 1 ـ علي عبد الامير علاوي ، احتلال العراق : ربح الحرب وخسارة السلام ، ط2 ، ترجمة عطا عبد الوهاب ، المؤسسة العربية للار اسات والنشر ، بيروت 2 - ـ راهول مهاجان ، السلطة المطلقة : الهيمنة الامريكية على العراق ، ماذا بعد ؟ ترجمة بشار حيدر ، الثركة العالمية للكتاب ، بيروت 2006 ، ص : 127 ، 1206 
للهدف الساعي اليه السياسي ، خدمةً لمصالحه وتناغماً مع قناعاته المتزمتة والعدوانية، وهذا ما ابتلى به العراق

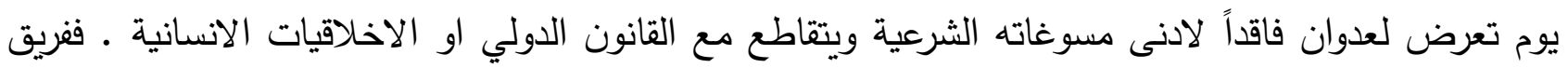
المحافظين الجدد " Neo - Conservative " وفي المقدمة منهم الرئيس الامريكي السابق - بوش الابن -

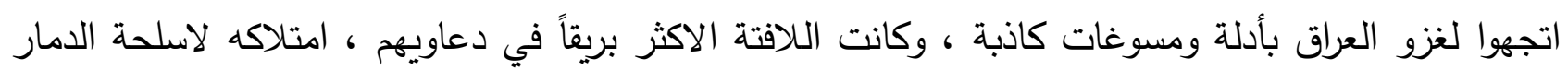

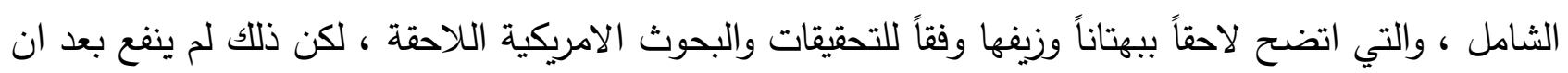

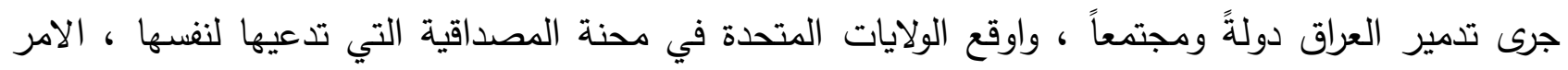

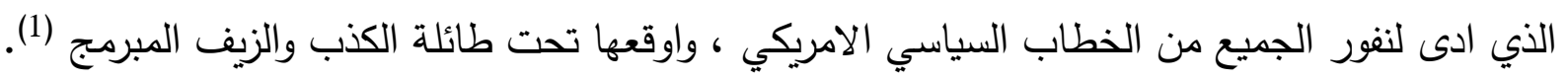

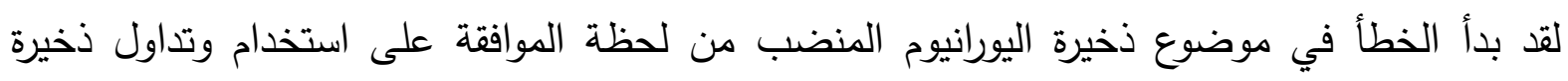
مصنعة من مادة مشعة تستهلك بكميات كبيرة في الميدان، وفي تطبيقات حربية "عادية" بواسطة افراد

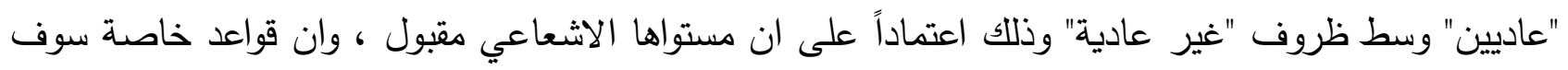

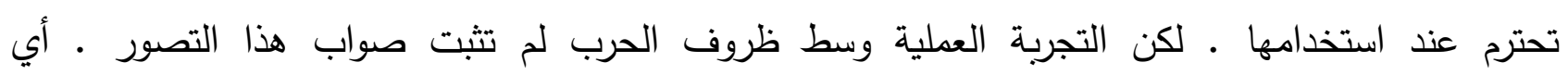
أن من اذن بتصنيع هذه الذخيرة واستخدامها ، كان يبحث عن قدرة القوة في ايقاع الاذى بالخصم ، ولئل وصولاً لاخضاعه (2) ، بغض النظر عن الآثار البيئية والحياتية الناجمة عن هذا الاستخدام ، مما سبب انبان ان تستطيل هذه الآثار السلبية المتعددة التأثير على مستقبل من جرى استخدامها ضدهم مما شوّه صورة مستقبل الاجيال

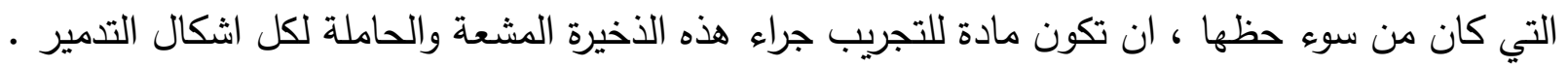
والمشكلة ان معظم الدراسات التي اجريت حول الموضوع ، قامت بها هيئات امريكية وبتمويل من وزارة

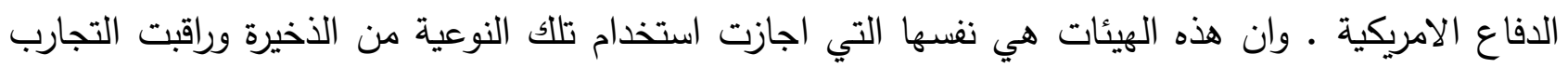
التي تمت عليها قبل السماح باستخدامها في الميدان ، وهي التي وضعت القان القواعد الارشادية للتعامل معها ، طبقاً

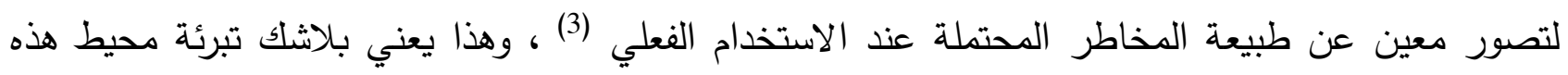
الذخيرة وصنّاعها ومستخدميها من اي قصور او احتمال وجود مخاطر محتملة عند استخدامها في الميدان ،

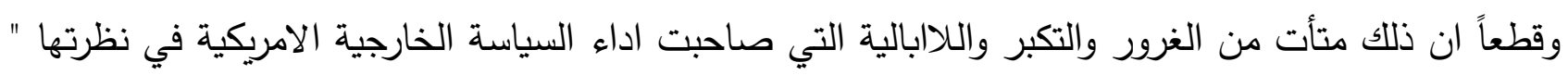
للآخرين " مما تسبب لاحقاً في العديد من الاخفاقات التي اضرت بسمعة الولايات المتحدة ، وطعنت في مصداقيتها (4) مخرين

ولاشك ان اخطاءاً كثيرة قد شابت تصور المخاطر وتحديد اثارها ، خاصةً وان تلك الدراسات ومن اجل اعطاء مصداقية لنتائجها ، وقد اعتمدت على دراسات سابقة اجريت على مجموعات من العاملين في مجال

1 - Vincent Bugliosi, The prosecution of George W. Bush for murder, Cambridge, MA: Vanguard press 2008 - P:246. 2 ـ ـ مجمو عة مؤلفين ، استر اتيجية التدمير ، مركز دراسات الوحدة العربية ، بيروت 2006 ، 201 ، ص : 106 ـ

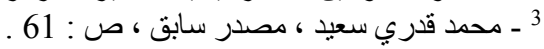

4 - Richard K. Betts, American Force: Dangers, Delusions, and Dilemmas in National security, Columbia University press, New York 2011, P: 236. 
الصناعات النووية والعاملين في المناجم ، التي تختلف ضروفهم بصورة جوهرية عن ضروف ميدان القتال ،

حيث يصعب اتباع قواعد أمان معقدة في اجواء ساخنة ومتسارعة ، وسط مخاطر اخرى كثيرة (1) . يضاف الى ذلك ، تقصير يصل الى حد جرائم الحرب ، في تجاهل تلوث البيئة بالغبار المشع وترسبه

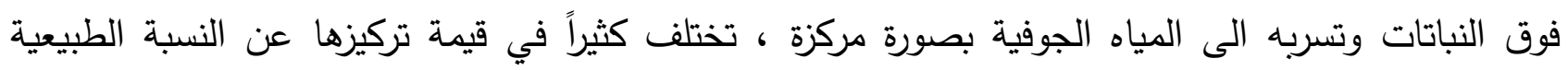

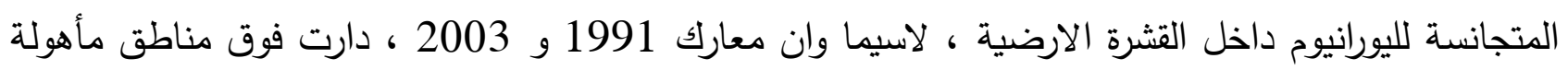

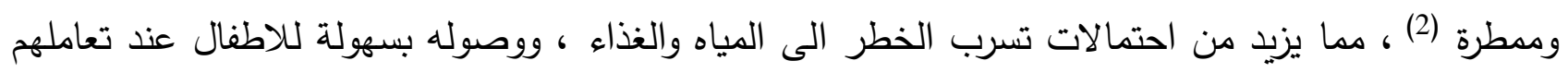

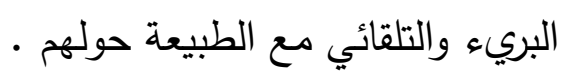
لذلك كان منطقياً وضرورياً ، ان تتولى المنظمات الدولية وفي المقدمة منها ، منظمة الصحة

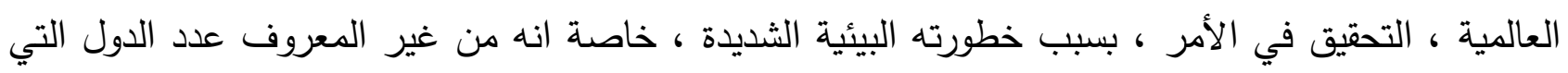

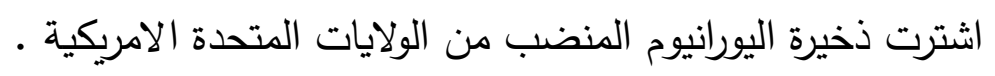

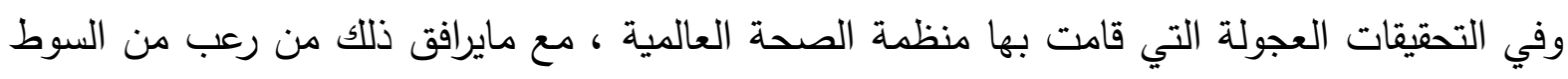

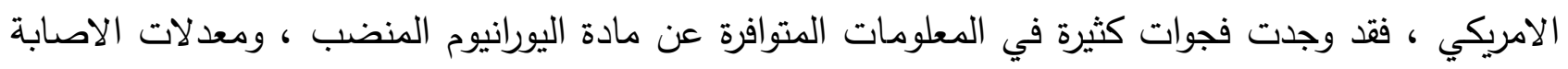

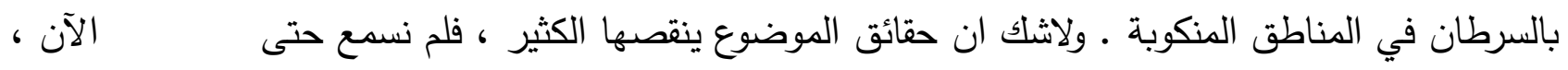

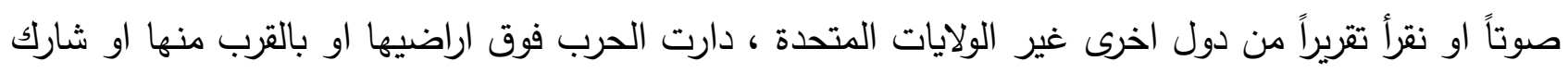
ابناء ها فيها (3) وفي النهاية ، تبقى معظم تفاصيل القصة ، امريكية في ملامحها وعناصرها ، الفكرة والسلاح والنخيرة والحرب ، وايضاً الضحايا ، ... وفي ذلك ، ليس تفريطاً بحقوق الناس ، بل تثجيع المجرمين من استمرار اساليهه في قتل البشر وتدمير الشواخص الحضارية والانسانية ، ... ودون عقاب .

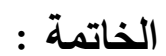

لاشك ان احد الحقائق المؤلمة في عالمنا المعاصر ، ان كثير من القوى الكبرى ، قد استخدمت وطّّعت

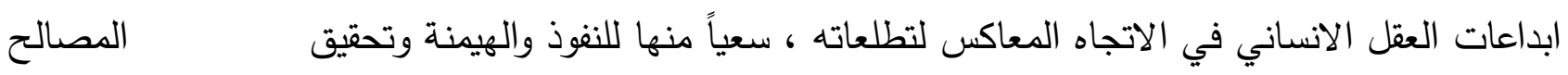
، حتى وان كانت ذات وقع اليم بالآخرين ، وهذا ما ادى الى اختلال في البيئة الامنية والحياتية التي يعيشها 
المجتمع الدولي، ودفع بعض القوى ، تحت هاجس الخوف ، ان تهدر الكثير من موارها وطاقاتها في سبيل تملك

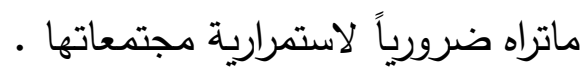

والطاقة النووية ، بكافة فروعها المتعددة ، لم توظف للآن بالاتجاه الايجابي للانسان ، قياساً لحجم

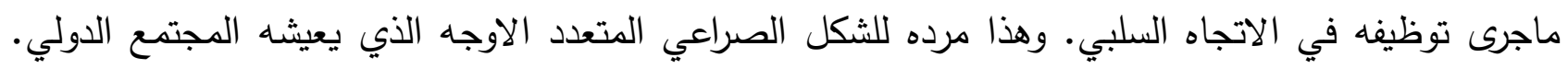

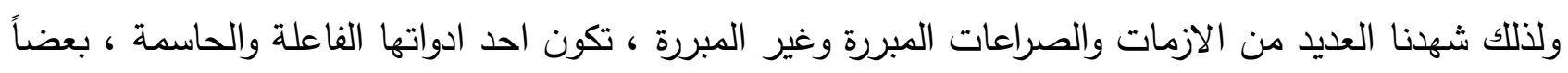
مما تولده الطاقة النووية ، وهذا ماحدث في العراق ، يوم اسرفت الولايات المتحدة في استخدام ذخيرة اليورانيوم

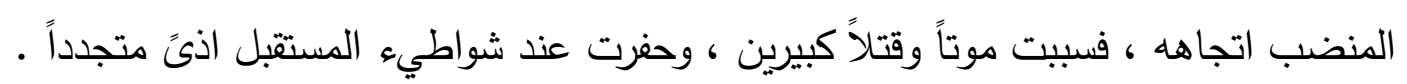
ان التحديات التي يواجهها المجتمع الدولي في هذا الجانب ، تستوجب تفعّيل المساهمات الايجابية التي

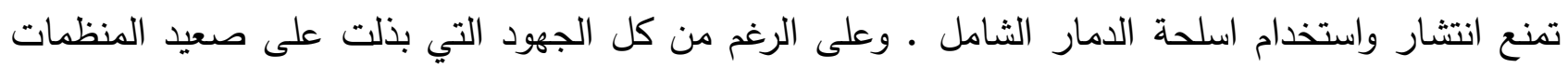

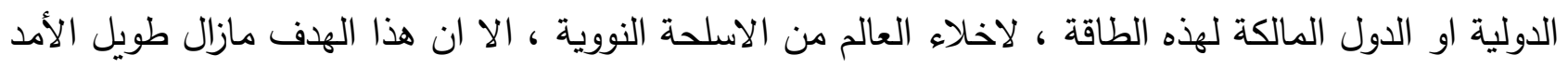

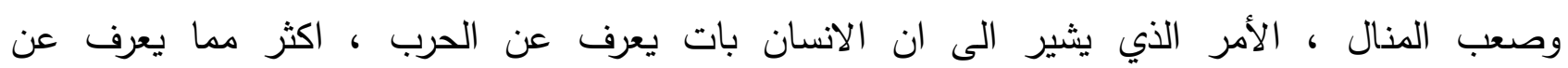

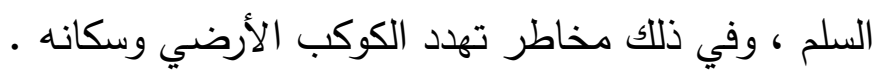

المصادر

أولاً : الكتب باللغة العربية

1. اسماعيل خليل الهيتي ، اليورانيوم المنضب ومخاطر اسلحته ، ط1 ، بيت الحكمة ، بغداد 2011 . 
2. الفريق الركن رعد مجيد الحمداني ، قبل ان يغادرنا التاريخ ، ط1 ، الدار العربية للعلوم ناشرون ، بيروت . 2007

3. ايمانويل تود ، مابعد الامبراطورية : دراسة في تفكك النظام الامريكي ، دار الساقي ، بيروت 2004 ـ 4. جاك بيولي ، البوسنة والهرسك : أداة بدون رادع ، ترجمة د. صالح المخزوم ، منشورات المؤسسة العربية

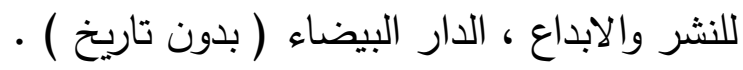

5. خضر عبد العباس وغسان هاشم الخطيب ، الطاقة الذرية واستخداماتها ، منشورات منظمة الطاقة الذرية العراقية ، بغداد 1988 - ابن

6. راهول مهاجان ، العلطة المطلقة : الهيمنة الامريكية على العراق ماذا بعد ؟ ترجمة بشار حيدر ، لشركة العالمية للكتاب ، بيروت 2006 ـ العان ،

7. صلاح الدين كمال داود ومحمد جمعة ، الاشعاع الذري ، ط1 ، دار الراتب الجامعية ، بيروت 1984 ـ 8. علي عبد الامير علاوي ، احتلال العراق : ربح الحرب وخسارة السلام ، ط2 ، ترجمة عطا عبد الوهاب ، المؤسسة العربية للدراسات والنشر ، بيروت 2009 ـ

9.

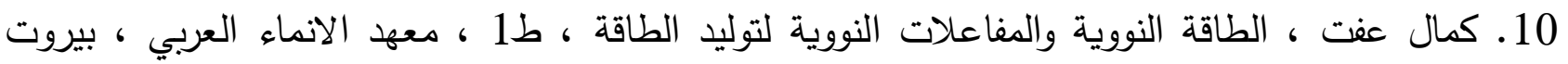
.1982

11. مجموعة مؤلفين ، ستراتيجية التدمير ، ط1 ، مركز دراسات الوحدة العربية ، بيروت 2006 ـ 12. نبيل محمود عبد المنعم ، مدخل الى تكنولوجيا الطاقة النووية ، ط1 ، مركز الكتب الثقافية ، القاهرة

ثانياً : الكتب والتقارير باللغة الانكليزية

1. J.s. Przemienieck " ed ", Critical Technologies for National Defennse, US Aiv force Institute of Technology, (AIAA), Washington 1991 .

2. Richard K. Betts, American Force : Dangers, Delusion, and Dilemmas in National security, Columbia University Press, New York 2011.

3. Vincent Bugliosi, TheProsecution of George W. Bush for Murder, Cambridge, MA: Vanguard press 2008.

4. Environmental Exposure Report: Depleted Uranium in the Gulf " II ", office of special Assistance for Defense, Report No: “ 1-800-497-6261 " December 13.2000 . 


$$
\begin{aligned}
& \text { 1. صحيفة العرب / لندن ، العدد (5698) في 1999/7/29 ـ محفة }
\end{aligned}
$$

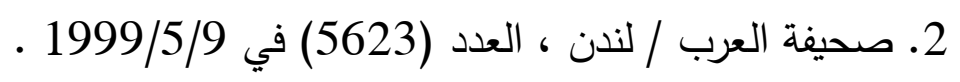

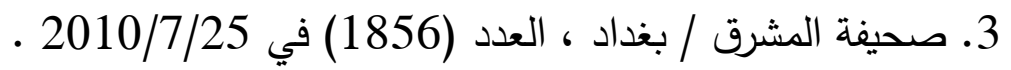

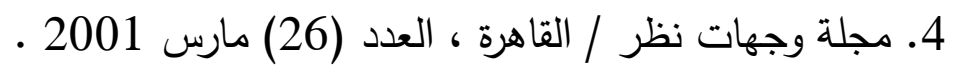

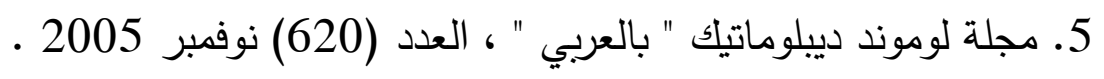

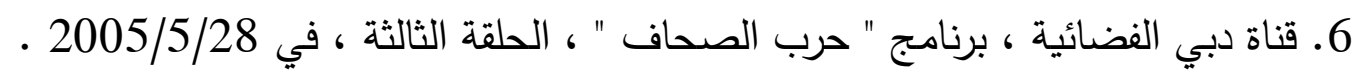

\section{Abstract}

The depleted Uranium (D4) is one of the nuclear power products . This material has been used in an ugly and fatal way against the civilians who were not party in any armed conflict. 
In Iraq, the United States has overused this weapon without any pressing military need in two periods: 1991 and 2003. This has caused renewing harm for the fattener of the next generations and their life's. The U.S.A. has given itself the permission for using this weapon although that it has be for bidden by Geneva Conventions that signed by U.S.A.

Sol the multiple forms of concerted diseases has widespread in many Iraqi Cities. These there have been on increase in birth defects. The clear - cut example has been in Fallujah.

The using of their internationally for bidden weapons specifically by U.S.A. is regarded a structural fault in the human, legal and moral norms are put aside running after power, interests and hegemony.

This is a clear image needs no lens to understand the mentality, humanity and morality of those who use thin weapon in no sense. 